Jurnal Ilmu Hukum

FAKULTAS HUKUM UMSU

\title{
KEWENANGAN PENYELESAIAN SENGKETA KONSUMEN LEMBAGA PEMBIAYAAN ANTARA BADAN PENYELESAIAN SENGKETA KONSUMEN (BPSK) DENGAN LEMBAGA ALTERNATIF PENYELESAIAN SENGKETA (LAPS)
}

\author{
Titia Tauhiddah, Busyra Azheri, Yussy A. Mannas \\ Fakultas Hukum Universitas Andalas, Jl. Limau Manis, Kecamatan Pauh, \\ Kota Padang, Sumatera Barat, Indonesia, 25163. \\ Email : titiatauhiddah24@yahoo.com, busyra@law.unand.ac.id, \\ yussymannas@yahoo.com
}

\begin{abstract}
Abstrak
Salah satu upaya pemerintah untuk menyelesaikan sengketa konsumen melalui jalur non litigasi adalah melalui Badan Penyelesian Sengketa Konsumen (BPSK). Selain itu Otoritas Jasa Keuangan (OJK) juga mengamanatkan pendirian lembaga guna menyelesaikan sengketa konsumen sektor jasa keuangan yaitu Lembaga Alternatif Penyelesaian Sengketa Konsumen (LAPS). Penelitian dilakukan secara normatif. Kajian ditekankan pada kewenangan penyelesaian sengketa konsumen pada lembaga pembiayaan antara BPSK dengan LAPS. Hasil penelitian menunjukkan bahwa BPSK berwenang menyelesaikan sengketa konsumen akhir, kewenangan yang dijalankan oleh BPSK diatur dalam Keputusan Menteri Perindustrian dan Perdagangan Republik Indonesia Nomor: 350/MPP/Kep/12/2001 tentang Pelaksanaan Tugas dan Wewenang Badan Penyelesaian Sengketa Konsumen dan Peraturan Menteri Perdagangan Republik Indonesia Nomor 06/M-DAG/PER/2/2017 tentang Badan Penyelesaian Sengketa Konsumen. Hanya saja mengenai putusan yang dikeluarkan BPSK terkait kasus lembaga pembiayaan khususnya yang mengandung unsur perjanjian kredit sering kali dibatalkan oleh Mahkamah Agung dikarenakan BPSK dinilai tidak berwenang untuk menyelesaikan sengketa yang terdapat unsur perjanjian. Kewenangan LAPS diatur dalam POJK Nomor 1/POJK.07/2014 tentang Lembaga Alternatif Penyelesaian Sengketa Sektor Jasa Keuangan. LAPS membagi lembaga penyelesaian sengketa sektor jasa keuangan dalam 6 lembaga, yang pendiriannya dilakukan OJK dengan bekerjasama dengan Lembaga Jasa Keuangan. LAPS yang berwenang menyelesaikan sengketa konsumen lembaga pembiayaan adalah BMPPVI (badan mediasi pergadaian, pembiayaan, dan modal ventura Indonesia).
\end{abstract}

\section{Kata Kunci: BPSK, BMPPVI, LAPS, Lembaga Pembiayaan, Sengketa Konsumen.}

\section{Abstract}

One of the government's efforts to resolve consumer disputes through non-litigation is through the Consumer Dispute Resolution Agency (BPSK). In addition, the Financial Services Authority (OJK) also mandates the establishment of institutions to resolve financial service sector consumer disputes, namely the Alternative Consumer Dispute Resolution Institute (LAPS). The study was conducted normatively. The study emphasizes the authority to resolve consumer disputes at financial institutions between BPSK and LAPS. The results show that BPSK has the authority to settle final consumer disputes, the authority exercised by BPSK is regulated in the Decree of the Minister of Industry and Trade of the Republic of Indonesia Number: 350 / MPP / Kep / 12/2001 concerning the Implementation of the Duties and Authorities of the Consumer Dispute Resolution Board and the Republic of Indonesia's Minister of Trade Regulation Indonesia Number 06 / M-DAG / PER / 2/2017 concerning the Consumer Dispute Resolution Board. It's just that the decisions issued by BPSK related to the case of financing institutions, 


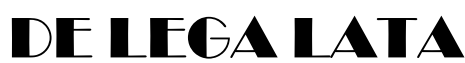

Jurnal Ilmu Hukum

FAKULTAS HUKUM UMSU
Kewenangan Penyelesaian Sengketa...(Titia Tauhiddah, dkk) Volume 5 Nomor 1, Januari - Juni 2020, 94-105 DOI: https://doi.org/10.30596/dll.v5i1.3472

especially those containing elements of the credit agreement are often canceled by the Supreme Court because BPSK is considered not authorized to settle disputes that contain the agreement element. The authority of LAPS is regulated in POJK Number 1 / POJK.07 / 2014 concerning Alternative Institutions for Dispute Resolution of the Financial Services Sector. LAPS divides financial service sector dispute resolution institutions into 6 institutions, the establishment of which is carried out by the OJK in collaboration with Financial Services Institutions. LAPS which has the authority to settle consumer financing company disputes is BMPPVI (the Indonesian mediation, financing and venture capital mediation body).

\section{Keywords: BPSK, BMPPVI, LAPS, Financial institutions, Consumer Disputes. PENDAHULUAN}

Lembaga pembiayaan merupakan salah satu dari bentuk lembaga keuangan yang berkembang dewasa ini. Pesatnya perkembangan lembaga keuangan khususnya lembaga pembiayaan di Indonesia menyebabkan pemerintah memberikan perhatian khusus dan berupaya untuk mencegah, menanggulangi serta mengatasi sengketa yang mungkin saja terjadi akibat dari pesatnya perkembangan lembaga keuangan baik itu lembaga keuangan bank maupun lembaga keuangan bukan bank. Dengan dibentuknya Undang-Undang Nomor 8 Tahun 1999 tentang Perlindungan Konsumen (selanjutnya disebut UUPK) merupakan salah satu perwujudan dari upaya pemerintah untuk melindungi masyarakat dari berbagai kecurangan yang mungkin dilakukan oleh para pelaku usaha, mengingat pada zaman milenial sekarang ini banyak kemungkinan kecurangan yang terjadi dan diharapkan agar masyarakat dan pelaku usaha dapat semakin cerdas dalam menyikapi segala tindak kecurangan ataupun kejahatan yang terjadi yang dapat merugikan para pihak.

Hukum perlindungan konsumen dewasa ini mendapatkan cukup perhatian karena menyangkut aturan-aturan guna mensejahterahkan masyarakat, bukan masyarakat selaku konsumen saja yang mendapat perlindungan, namun juga pelaku usaha yang juga mempunyai hak yang sama untuk mendapatkan perlindungan, masing-masing ada hak dan kewajiban (Celina Tri siwi Kristiyanti, 2008, h. 1). Hanya saja memang dalam kenyataannya pada umumnya memang konsumen lah yang selalu berada dipihak yang dirugikan (Janus Sidabalok, 2014, h. 4). Perlindungan konsumen dinilai sangat perlu ditegakkan agar dapat meminimalisir kemungkinan yang dapat menimbulkan kerugian, serta hal ini erat kaitannya dengan upaya mensejahterakan masyarakat dalam hal pembangunan dan perkembangan perekonomian umumnya dan khususnya di bidang perindustrian dan perdagangan nasional.

Penyelesaian sengketa dapat dilakukan melalui jalur litigasi (lembaga peradilan) dan non litigasi (di luar pengadilan). Pelaksanaan penyelesaian sengketa konsumen diluar pengadilan atau non litigasi dilaksanakan oleh Badan Penyelesaian Sengketa Konsumen (yang selanjutnya disebut BPSK), BPSK dibentuk berdasarkan UUPK, sebagaimana yang dicantumkan dalam Pasal 49 Ayat (1) UUPK disebutkan bahwa pemerintah membentuk Badan Penyelesaian Sengketa Konsumen di Daerah Tingkat II untuk penyelesaian sengketa konsumen diluar pengadilan. BPSK didirikan untuk memfasilitasi para konsumen yang merasa dirugikan untuk mengajukan gugatan ke pelaku melalui BPSK, yang mekanisme gugatannya dilakukan secara sukarela dari kedua belah pihak yang bersengketa (Celina Tri siwi Kristiyanti, 2008, h. 126). 


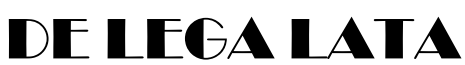

Jurnal Ilmu Hukum

FAKULTAS HUKUM UMSU
Kewenangan Penyelesaian Sengketa...(Titia Tauhiddah, dkk) Volume 5 Nomor 1, Januari - Juni 2020, 94-105 DOI: https://doi.org/10.30596/dll.v5i1.3472

Baru-baru ini Otoritas Jasa keuangan (yang selanjutnya disebut OJK) selaku lembaga independen negara yang tugas dan wewenangnya adalah melakukan pengawasan terhadap jasa keuangan mengamanatkan untuk membentuk suatu lembaga yang dapat dijadikan sebagai alternatif dari penyelesaian sengketa konsumen dibidang jasa keuangan dengan cara non litigasi atau diluar pengadilan melalui Lembaga Alternatif Penyelesaian Sengketa (yang selanjutnya disebut LAPS), LAPS dibentuk berdasarkan ketentuan Peraturan Otoritas Jasa Keuangan (yang selanjutnya disebut POJK) Nomor 1/POJK.07/2013 tentang Perlindungan Konsumen Sektor Jasa Keuangan yang disebutkan pada BAB III mengenai Pengaduan Konsumen dan Pemberian Fasilitas Penyelesaian Pengaduan Oleh Otoritas Jasa Keuangan, bab tersebut menjelaskan bahwa OJK memberikan wadah kepada konsumen untuk melakukan pengaduan jika terjadi suatu sengketa antara pelaku usaha dengan konsumen, dan OJK juga berupaya untuk menyelesaikan sengketa tersebut melalui wadah yang telah disediakan, dan wadah yang dimaksud adalah LAPS tersebut. LAPS diatur dalam POJK Nomor 1/POJK.07/2014 tentang Lembaga Alternatif Penyelesaian Sengketa Sektor Jasa Keuangan.

Sebagai lembaga yang baru saja dihadirkan di dalam masyarakat guna menyelesaikan sengketa konsumen sektor jasa keuangan tentunya masih belum banyak masyarakat dalam hal ini konsumen yang menyadari bahwasanya LAPS pun telah hadir untuk siap membantu masyarakat dalam menyelesaikan sengketa konsumen termasuk konsumen lembaga pembiayaan. Berdasarkan data yang didapat masih banyak yang beranggapan bahwa LAPS memiliki fungsi, tugas, kewajiban dan wewenangnya dengan BPSK sebagaimana yang telah dijelaskan di awal, sehingga akan banyak opini yang bermunculan akibat dari didirikannya LAPS, apa alasan pemerintah memberikan izin berdirinya lembaga yang fungsi, tugas, kewajiban dan wewenangnya hampir sama tanpa membubarkan salah satunya, sedangkan jika dilihat dalam prakteknya BPSK sebagai lembaga penyelesaian sengketa konsumen yang pertama saja masih belum berjalan dengan efektif, karena alasan tersebut maka penulis tertarik melakukan penelitian dan menetapkan judul penulisan dengan judul "Kewenangan Penyelesaian Sengketa Konsumen Pada Lembaga Pembiayaan Antara Badan Penyelesaian Sengketa Konsumen (Bpsk) Dengan Lembaga Alternatif Penyelesaian Sengketa (Laps)”.

\section{METODE PENELITIAN}

Metode penelitian yang digunakan pada penelitian ini adalah menggunakan penelitian yuridis-normatif yaitu penulisan hukum dengan melihat norma dan teori hukum yang relevan berdasarkan bahan-bahan hukum, baik bahan hukum primer, sekunder dan tersier. Pendekatan yang dipergunakan adalah pendekatan perundang-undangan. Sumber data yang dipergunakan dalam penelitian ini adalah sumber data sekunder yang berasaal dari bahan hukum primer, sekunder dan tersier. Berdasarkan bahan hukum tersebut diantaranya digunakan sesuai dengan pembahasan yang dikaji, karena itulah penelitian ini hanya ditujukan pada peraturan-peraturan tertulis atau bahan-bahan hukum.

\section{PEMBAHASAN DAN ANALISIS}

Badan Penyelesaian Sengketa Konsumen (BPSK) hadir untuk melindungi konsumen dan para pelaku usaha dalam menghadapi permasalahan yang mungkin saja terjadi antara para 


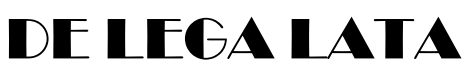

Jurnal Ilmu Hukum

FAKULTAS HUKUM UMSU
Kewenangan Penyelesaian Sengketa...(Titia Tauhiddah, dkk) Volume 5 Nomor 1, Januari - Juni 2020, 94-105 DOI: https://doi.org/10.30596/dll.v5i1.3472

pihak, yang dapat merugikan salah satu pihak ataupun masing-masing pihak. Badan Penyelesaian Sengketa Konsumen (BPSK) merupakan salah satu wujud upaya pemerintah dalam menanggulangi dan mengatasi permasalahan terkait sengketa konsumen. BPSK merupakan lembaga yang dibentuk dengan mengambil format suatu small-claim institution, (Susanti Adi Nugroho, 2011, h. 74). yang diharapkan dapat menjawab tuntutan masyarakat agar proses berperkara dapat dilangsungkan dengan cepat, sederhana dan biaya murah. Dengan demikian BPSK hanya menerima perkara-perkara yang nilai kerugiannya berskala kecil dan bersifat sederhana (Marianus Gaharpung, 2000, h. 43).

Badan Penyelesaian Sengketa Konsumen (BPSK) didirikan berdasarkan ketentuan Pasal 45 Ayat (1) UUPK yang menyatakan bahwa "penyelesaian sengketa konsumen dapat diselesaikan melalui lembaga yang bertugas menyelesaikan sengketa konsumen dan pelaku usaha, dan peradilan yang berada dilingkungan peradilan umum”. Berdasarkan pengamalan dari UUPK inilah akhirnya pemerintah mendirikan Badan Penyelesaian Sengketa Konsumen yang dikenal dengan istilah BPSK. Untuk melaksanakan amanat dari UUPK, pemerintah menerbitkan Keputusan Menteri Perindustrian dan Perdagangan (selanjutnya disebut Kepmenperindag) Republik Indonesia Nomor 350/MPP/Kep/12/2001 tentang Pelaksanaan Tugas dan Wewenang Badan Penyelesaian Sengketa Konsumen, yang dijadikan dasar hukum pembentukan BPSK adalah Pasal 49 Ayat (1) UU Perlindungan Konsumen jo. Kepmenperindag Nomor 350/MPP/Kep/12/2001 yang mengatur bahwa setiap kota atau kabupaten harus dibentuk BPSK.

Pasal 49 Ayat (1) UU Perlindungan Konsumen yang menyebutkan bahwa pemerintah membentuk badan penyelesaian sengketa konsumen di Daerah Tingkat II untuk penyelesaian sengketa diluar pengadilan. Daerah tingkat II yang dimaksud disini adalah daerah Kabupaten/kota namun sejak diberlakunya UU Nomor 22 Tahun 1999 tentang Pemerintahan Daerah istilah Daerah Tingkat II tidak lagi dipergunakan, aturan mengenai pembagian daerah sebagaimana dicantumkan dalam Pasal 2 Ayat (1) UU No. 22 Tahun 1999 tentang Pemerintahan Daerah bahwa "Wilayah Negara Kesatuan Republik Indonesia dibagi dalam Daerah Propinsi, Daerah Kabupaten, dan Daerah Kota”. Pendirian BPSK dilakukan secara bertahap oleh pemerintah dan hingga saat ini BPSK sudah tersebar hampir diseluruh wilayah Indonesia, hanya saja pembentukan BPSK di Kota Jakarta Barat dan Jakarta Pusat Belum dilakukan karena terkait dengan UU Nomor 34 Tahun 1999 tentang Pemerintahan Provinsi Daerah Khusus Ibukota Negara Republik Indonesia Jakarta, argumentasi yang dikemukakan adalah bahwa otonomi daerah untuk Provinsi Daerah Khusus Ibu Kota Jakarta bukan pada kota, karena itu Jakarta Barat dan Jakarta Pusat tidak dapat dibentuk BPSK (Susanti Adi Nuggroho, 2011, Hlm 76).

Lain halnya dengan LAPS, LAPS hadir untuk membantu OJK guna menjalankan fungsi, tugas dan kewenangan OJK dengan lebih kondusif dan lebih baik lagi, OJK mengamanatkan untuk membentuk suatu lembaga khusus terkait penyelesaian sengketa konsumen dibidang jasa keuangan dengan cara non litigasi atau diluar pengadilan melalui Lembaga Alternatif Penyelesaian sengketa (LAPS). LAPS diharapkan juga mampu mewujudkan salah satu tujuan dibentuknya OJK yakni yang tercantum dalam Pasal 4 UU OJK yang menjelaskan bahwasanya salah satu tujuan OJK dibentuk adalah agar seluruh masyarakat mampu melindungi konsumen 


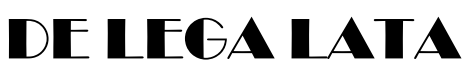

Jurnal Ilmu Hukum

FAKULTAS HUKUM UMSU
Kewenangan Penyelesaian Sengketa...(Titia Tauhiddah, dkk) Volume 5 Nomor 1, Januari - Juni 2020, 94-105 DOI: https://doi.org/10.30596/dll.v5i1.3472

dan juga masyarakat. Sebagaimana yang dijelaskan di dalam penjelasan POJK Nomor: 1/POJK.07/2013 tentang Perlindungan Konsumen Sektor Jasa Keuangan menjelaskan bahwa globalisasi dalam sistem keuangan dan pesatnya kemajuan dibidang teknologi informasi serta inovasi finansial telah menciptakan sistem keuangan yang sangat kompleks, dinamis dan saling terkait antar-subsektor keuangan baik dalam hal produk maupun kelembagaan. Sehingga beberapa hal yang menjadi perhatian OJK diantaranya adalah pengawasan sektor jasa keuangan yang terintegrasi (konglomerasi), praktik perlindungan konsumen yang sama disemua sektor jasa keuangan, tindakan yang mencerminkan moral hazard dan belum optimalnya perlindungan konsumen sektor jasa keuangan. Perlindungan konsumen di sektor jasa keuangan bertujuan menciptakan sistem perlindungan konsumen yang andal, meningkatkan pemberdayaan konsumen dan menumbuhkan kesadaran pelaku usaha jasa keuangan mengenai pentingnya perlindungan konsumen sehingga mampu meningkatkan kepercayaan masyarakat pada sektor jasa keuangan. Sehingga sangat diperlukan adanya suatu lembaga yang dapat mewujudkan hal tersebut.

Lembaga Alternatif Penyelesaian Sengketa dibentuk berdasarkan ketentuan Peraturan Otoritas Jasa Keuangan (yang selanjutnya disebut POJK) Nomor 1/POJK.07/2013 tentang Perlindungan Konsumen Sektor Jasa Keuangan yang disebutkan pada BAB III mengenai Pengaduan Konsumen dan Pemberian Fasilitas Penyelesaian Pengaduan Oleh Otoritas Jasa Keuangan, bab tersebut menjelaskan bahwa OJK memberikan wadah kepada konsumen untuk melakukan pengaduan jika terjadi suatu sengketa antara pelaku usaha dengan konsumen, dan OJK juga berupaya untuk menyelesaikan sengketa tersebut melalui wadah yang telah disediakan, dan wadah yang dimaksud adalah LAPS tersebut. LAPS diatur dalam POJK Nomor 1/POJK.07/2014 tentang Lembaga Alternatif Penyelesaian Sengketa Sektor Jasa Keuangan.

Pasal 1 angka 2 POJK Nomor 1/POJK.07/2014 tentang Lembaga Alternatif Penyelesaian Sengketa Sektor Jasa Keuangan menjelaskan bahwa "Lembaga Alternatif Penyelesaian Sengketa Konsumen adalah lembaga yang melakukan penyelesaian sengketa di luar pengadilan". Melalui POJK ini kita dapat mengetahui bahwa LAPS merupakan lembaga yang didirikan oleh OJK guna membantu OJK untuk melaksanakan tugas dan kewajibannya berkaitan dengan penyelesaian sengketa jasa keuangan dengan cara non litigasi.

Pengumuman OJK Nomor PENG-1/D.07/2016 tentang Daftar Lembaga Alternatif Penyelesaian Sengketa di Sektor Jasa Keuangan menjelaskan bahwasanya lembaga penyelesaian sengketa di sektor jasa keuangan antara lain : Badan Mediasi dan Arbitrase Asuransi Indonesia (BMAI) untuk penyelesaian sengketa sektor perasuransian, Badan Arbitrase Pasar Modal Indonesia (BAPMI) untuk penyelesaian sengketa sektor pasar modal, Badan Mediasi Dana Pensiun (BMDP) untuk penyelesaian sengketa sektor dana pensiun, Lembaga Alternatif Penyelesaian Sengketa Perbankan Indonesia (LAPSPI) untuk penyelesaian sengketa sektor perbankan, Badan Arbitrase dan Mediasi Perusahaan Penjamin Indonesia (BAMPPI) untuk penyelesaian sengketa sektor penjaminan, Badan Mediasi Pembiayaan, Pergadaian, dan Ventura Indonesia (BMPPVI) untuk penyelesaian sengketa sektor pembiayan, pergadaian dan modal ventura.

Badan Mediasi Pembiayaan, Pergadaian, dan Modal Ventura Indonesia (BMPPVI) didirikan oleh OJK guna melakukan penyelesaian sengketa konsumen khusus sektor 


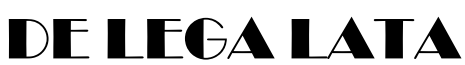

Jurnal Ilmu Hukum

FAKULTAS HUKUM UMSU
Kewenangan Penyelesaian Sengketa...(Titia Tauhiddah, dkk) Volume 5 Nomor 1, Januari - Juni 2020, 94-105 DOI: https://doi.org/10.30596/dll.v5i1.3472

pembiayan, pergadaian dan modal ventura dengan motto pendirian yakni "Mendamaikan dan Menyelesaikan". Mendamaikan dan menyelesaikan adalah suatu upaya yang dilakukan untuk membantu para pihak yang bersengketa agar dapat menyepakati suatu keadaan yang dapat diterima oleh masing-masing pihak yang bersengketa sebagai penyelesaian atas sengketa yang dihadapi dan ditindak lanjuti dengan kesepakatan bersama untuk mengakhiri segala bentuk perselisihan dalam permasalahan yang disengketakan dikemudian hari. Motto ini menggambarkan bahwa BMPPVI dalam menjalankan perannya menyelesaikan sengketa pembiayaan dan pegadaian selalu mengedepankan upaya mediasi dengan tujuan agar tercapainya suatu perdamaian antara para pihak yang bersengketa, namun apabila tidak tercapai maka atas kesepakatan untuk atau dalam menempuh mediasi maka BMPPVI akan membantu para pihak menyelesaikan sengketa melalui model penyelesaian ajudikasi dan arbitrase dimana para ajudikator dan arbitrer BMPPVI akan memeriksa sengketa yang terjadi dan menetapkan putusan berdasarkan fakta dan bukti, serta pertimbangan hukum yang berlaku (Melalui: www.bmppvi.com/profil/).

Badan Mediasi Pembiayaan, Pergadaian, dan Modal Ventura Indonesia mulai menjalankan peran dan fungsinya sebagai Lembaga Alternatif Penyelesaian Sengketa pada tanggal 11 April 2017. Dasar hukum didirikannya BMPPVI adalah POJK Nomor 1/POJK.07/2013 tentang Perlindungan Konsumen Sektor Jasa Keuangan yang disebutkan pada BAB III mengenai Pengaduan Konsumen dan Pemberian Fasilitas Penyelesaian Pengaduan Oleh Otoritas Jasa Keuangan. Dan Pasal 1 angka 2 POJK Nomor 1/POJK.07/2014 tentang Lembaga Alternatif Penyelesaian Sengketa Sektor Jasa Keuangan menjelaskan bahwa "Lembaga Alternatif Penyelesaian Sengketa Konsumen adalah lembaga yang melakukan penyelesaian sengketa di luar pengadilan". Serta Pengumuman OJK Nomor PENG1/D.07/2016 tentang Daftar Lembaga Alternatif Penyelesaian Sengketa di Sektor Jasa Keuangan. LAPS-BMPPVI memiliki visi yakni menjadi lembaga alternatif penyelesaian sengketa di sektor jasa Pembiayaan, Pergadaian dan Modal Ventura Indonesia yang profesional dan terpercaya dengan misi menyediakan sistem dan sumber daya manusia yang dapat menyelesaikan sengketa tebaik guna melindungi hak konsumen serta pertumbuhan industri secara adil dan berimbang (Melalui: www.bmppvi.com/profil/).

Pengertian konsumen jika dilihat dalam peraturan perundang-undangan BPSK dengan LAPS memiliki pengertian yang berbeda, bedasarkan Pasal 1 angka 2 UUPK menjelaskan bahwa "Konsumen adalah setiap orang pemakai barang dan/atau jasa yang tersedia dalam masyarakat baik bagi kepentingan diri sendiri, keluarga, orang lain, maupun mahluk hidup lain dan tidak untuk diperdagangkan." Pengertian konsumen menurut UUPK diatas sama dengan pengertian konsumen pada Pasal 1 angka 2 Kepmenperindag RI Nomor : 350/MPP/Kep/12/2001 tentang Pelaksanaan Tugas Dan Wewenang Badan Penyelesaian Sengketa Konsumen. Berdasarkan penjelasan Pasal 1 angka 2 UUPK "Di dalam kepustakaan ekonomi dikenal dengan istilah konsumen akhir dan konsumen antara. Konsumen akhir adalah pengguna atau pemanfaat akhir dari suatu produk, sedangkan konsumen antara adalah konsumen yang menggunakan suatu produk sebagai bagian dari proses produksi suatu produk lainnya. Pengertian konsumen dalam Undang-Undang ini adalah Konsumen akhir". Konsumen antara dan konsumen akhir dibedakan berdasarkan tujuan ataupun pemanfaatan barang dan/atau 


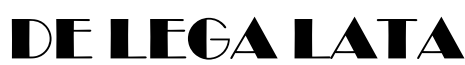

Jurnal Ilmu Hukum

FAKULTAS HUKUM UMSU
Kewenangan Penyelesaian Sengketa...(Titia Tauhiddah, dkk) Volume 5 Nomor 1, Januari - Juni 2020, 94-105 DOI: https://doi.org/10.30596/dll.v5i1.3472

jasa yang digunakan, konsumen antara mendapatkan barang dan/atau jasa guna suatu proses produksi ataupun untuk menghasilkan barang dan/atau jasa lagi ataupun untuk diperdagangkan kembali dengan tujuan mendapatkan keuntungan, sedangkan konsumen akhir mendapatkan barang dan/atau jasa dengan tujuan memenuhi kebutuhan hidupnya dan tidak untuk diperdagangkan kembali guna mendapatkan keuntungan. Berdasarkan penjelasan Pasal 1 angka 2 UUPK diatas dapat diketahui bahwasanya konsumen yang dimaksud oleh BPSK adalah sama dengan yang dimaksud oleh UUPK yakni Konsumen Akhir, UUPK tidak memberikan perlindungan kepada Konsumen Antara.

Berdasarkan Pasal 1 angka 11 POJK Nomor 1/POJK.07/2014 tentang Lembaga Alternatif Penyelesaian Sengketa Konsumen Sektor Jasa Keuangan menjelaskan bahwa "Konsumen adalah pihak-pihak yang menempatkan dananya dan/atau memanfaatkan pelayanan yang tersedia di Lembaga Jasa Keuangan antara lain nasabah pada Perbankan, pemodal di Pasar Modal, pemegang polis pada Peransuransian, dan peserta pada Dana Pensiun, berdasarkan peraturan perundang-undangan di sektor jasa keuangan." Pengertian konsumen menurut POJK ini sama dengan pengertian konsumen pada Pasal 1 angka 15 UU OJK.

Diketahui bahwa yang dimaksud dengan konsumen menurut LAPS OJK memiliki makna lebih sempit dibandingkan dengan konsumen pada UUPK, konsumen yang dimaksud LAPS OJK adalah pihak pengguna jasa lembaga keuangan yakni konsumen sektor jasa keuangan yang menempatkan dananya dan/atau memanfaatkan pelayanan yang tersedia di lembaga jasa keuangan. Pihak yang menempatkan dana (pelaku usaha) dapat perseorangan maupun badan usaha baik yang berbadan hukum maupun tidak berbadan hukum. Sedangkan yang dimaksud konsumen oleh LAPS-BMPPVI adalah konsumen pengguna jasa lembaga pembiayaan, pergadaian dan juga konsumen pengguna jasa modal ventura Indonesia.

Pengertian pelaku usaha dalam Pasal 1 angka 3 UUPK "pelaku usaha adalah setiap orang perseorangan atau badan usaha, baik yang berbentuk badan hukum maupun bukan badan hukum yang didirikan dan berkedudukan atau melakukan kegiatan dalam wilayah hukum negara Republik Indonesia, baik sendiri maupun bersama-sama melalui perjanjian menyelenggarakan kegiatan usaha dalam berbagai bidang ekonomi”. Pelaku usaha memiliki pengertian pelaku usaha yang sama dengan ketentuan Pasal 1 angka 3 menurut Kepmenperindag RI Nomor: 350/MPP/Kep/12/2001 tentang Pelaksanaan Tugas Dan Wewenang Badan Penyelesaian Sengketa Konsumen menjelaskan. Pelaku usaha disini termasuk juga perusahaan, korporasi, BUMN, koperasi, Importir, pedagang, dan juga distributor.

Berdasarkan Pasal 1 angka 1 POJK Nomor 1/POJK.07/2013 tentang Perlindungan Konsumen Sektor Jasa Keuangan, pelaku usaha jasa keuangan adalah "Bank Umum, Bank Perkreditan Rakyat, Perusahaan Efek, Penasihat Investasi, Bank Kustodian, Dana Pensiun, Perusahaan Asuransi, Perusahaan Reasuransi, Lembaga Pembiayaan, Perusahaan Gadai, Dan Perusahaan Penjamin, baik yang melaksanakan kegiatan usahanya secara konvensional maupun secara syariah". Jadi, pelaku usaha yang dimaksud oleh LAPS-BMPPVI disini adalah pelaku usaha yang menjalankan kegiatan usahanya dibidang pembiayaan, pergadaian, dan modal ventura. 


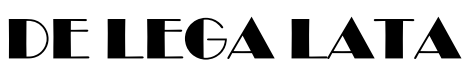

Jurnal Ilmu Hukum

FAKULTAS HUKUM UMSU
Kewenangan Penyelesaian Sengketa...(Titia Tauhiddah, dkk) Volume 5 Nomor 1, Januari - Juni 2020, 94-105 DOI: https://doi.org/10.30596/dll.v5i1.3472

Penjabaran di atas terlihat bahwasanya yang dimaksud pelaku usaha menurut BPSK adalah orang perseorangan atau badan usaha, baik yang berbentuk badan hukum maupun bukan badan hukum yang didirikan dan berkedudukan atau melakukan kegiatan dalam wilayah hukum negara Republik Indonesia baik sendiri maupun bersama-sama melalui perjanjian menyelenggarakan kegiatan usaha dalam berbagai bidang ekonomi. Sedangkan menurut LAPS BMPPVI pelaku usaha adalah lembaga yang menjalankan kegiatan usahanya dibidang pembiayaan, pergadaian, dan juga modal ventura.

Melalui penjelasan di atas dapat kita lihat bahwasanya penyelesaian sengketa konsumen di Indonesia dapat dilakukan melalui BPSK dan juga melalui LAPS, khusus untuk menyelesaikan sengketa konsumen pada lembaga pembiayaan melalui LAPS akan dilaksanakan oleh Badan Mediasi Pembiayaan, Pergadaian Dan Modal Ventura Indonesia (BMPPVI), hal ini karena LAPS dalam melaksanakan tugas dan kewenangannya selaku badan penyelesaian sengketa konsumen melakukan pembagian untuk menangani atau menyelesaikan masing-masing sengketa tergantung dari sektor jasa keuangan yang mengalami sengketa, yang totalnya ada 6 (enam badan) yang didirikan secara terpisah untuk menyelesaikan sengketa konsumen sektor jasa keuangan. Seperti yang telah diketahui bahwa BPSK didirikan sebagai amanat dari UU Perlindungan konsumen sedangkan LAPS didirikan melalui POJK berdasarkan kewenangan OJK selaku lembaga independen negara yang bertugas melakukan pengaturan dan pengawasan terhadap sektor jasa keuangan.

Penyelesaian sengketa melalui BPSK dan juga LAPS-BMPPVI ini sama-sama mengatur penyelesaian sengketa konsumen melalui jalur non litigasi yaitu penyelesaian sengketa diluar pengadilan, yang pada dasarnya baik di dalam UUPK maupun di dalam POJK LAPS memiliki kesamaan dimana kedua aturan lembaga ini memberikan kebebasan kepada konsumen untuk menentukan pilihan dalam menyelesaikan sengketa konsumen yang mereka hadapi, apakah akan diselesaikan secara ligasi (melalui pengadilan) ataupun non litigasi (diluar pengadilan). Selain itu keduanya sama-sama mewajibkan terlebih dahulu kepada para pihak untuk menyelesaikan sengketa secara internal terlebih daluhu sebelum memutuskan untuk menyelesaikan sengketa baik itu melalui BPSK ataupun LAPS-BMPPVI, yang mana sudah diterangkan sebelumnya bahwa setiap lembaga keuangan wajib memiliki badan penyelesaian sengketa sendiri di dalam lembaga jasa keuangan yang mereka miliki sehingga jika terjadi suatu permasalahan antara konsumen dan pelaku usaha maka konsumen terlebih dahulu melaporkan kepada lembaga jasa keuangan yang bersangkutan dan diselesaikan melalui lembaga jasa keuangan yang bersangkutan tersebut. Dan dalam hal penyelesaian sengketa pada lembaga jasa keuangan yang bersangkutan tersebut, lembaga tidak diperbolehkan mengambil keuntungan atas pelaporan konsumen dengan kata lain memungut biaya untuk menyelesaikan sengketa. Pada tahapan inilah jika tidak didapatkan penyelesaian dalam sengketa tersebut maka para pihak akan menentukan apakah akan menyelesaikan secara litigasi ataupun non litigasi melalui BPSK ataupun LAPS-BMPPVI.

Selain itu, masing-masing lembaga penyelesaian sengketa baik BPSK maupun LAPSBMPPVI memiliki tujuan untuk mendamaikan sengketa yang terjadi antara pelaku usaha dan juga konsumen, sehingga jika konsumen dan pelaku usaha sepakat untuk melakukan penyelesaian sengketa baik melalui BPSK ataupun LAPS-BMPPVI maka pada saat para pihak 


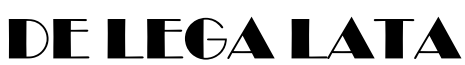

Jurnal Ilmu Hukum

FAKULTAS HUKUM UMSU
Kewenangan Penyelesaian Sengketa...(Titia Tauhiddah, dkk) Volume 5 Nomor 1, Januari - Juni 2020, 94-105 DOI: https://doi.org/10.30596/dll.v5i1.3472

telah mengajukan permohonan dan telah diperiksa dan dinyatakan lengkap oleh masing-masing lembaga maka selanjutnya akan dilakukan pemanggilan, dan pada saat pertemuan pertama kali itulah nantinya baik BPSK ataupun LAPS-BMPPVI akan terlebih dahulu menyarankan dan mengarahkan para pihak untuk melakukan damai melalui mediasi.

Namun terdapat beberapa perbedaan penyelesaian sengketa antara UUPK dan LAPS OJK, yang mana menurut UUPK, penyelesaian sengketa konsumen diluar pengadilan dilaksanakan melalui BPSK sedangkan menurut LAPS OJK, penyelesaian sengketa konsumen sektor jasa keuangan diluar pengadilan dilaksanakan melalui LAPS. Selain itu, BPSK memiliki kewenangan penyelesaian sengketa konsumen secara umum, yaitu sengketa konsumen yang berkaitan dengan barang dan/atau jasa dan juga pengertian konsumen pada BPSK lebih luas jika dibandingkan dengan konsumen LAPS, dimana konsumen disini adalah konsumen akhir termasuk konsumen lembaga pembiayaan, sedangkan LAPS memiliki kewenangan penyelesaian sengketa khusus untuk penyelesaian sengketa konsumen sektor jasa keuangan yang termasuk di dalamnya lembaga pembiayaan dan konsumen di dalam LAPS bermakna lebih sempit jika dibadingkan dengan BPSK yang mana konsumen disini hanya konsumen pada lembaga jasa keuangan termasuk di dalamnya konsumen lembaga pembiayaan. Namun kedua lembaga ini sama-sama memegang prinsip untuk menyelesaikan sengketa secara adil, tidak untuk menguntungkan sebelah pihak saja. Serta penyelesaian sengketa melalui BPSK diselesaikan melalui penyelesaian secara konsiliasi, mediasi dan arbitrase yang bukan merupakan proses penyelesaian berjenjang, begitupun penyelesaian sengketa melalui LAPSBMPPVI yang diselesaikan melalui penyelesaian sengketa secara mediasi, ajudikasi, dan arbitrase juga bukan merupakan proses penyelesaian sengketa berjenjang yang harus dilewati setiap tahapannya, hanya saja penyelesaian sengketa dilakukan tergantung daripada pilihan para pihak.

Mengenai pendanaan, BPSK tidak memungut biaya apapun terhadap sengketa konsumen yang diselesaikan melaui BPSK, hal ini dikarenakan BPSK pendanaannya dibebankan kepada Anggaran Pendapatan dan belanja Daerah Povinsi (APBD), jadi setiap biaya penyelenggaraan BPSK baik itu biaya operasional, dan honorarium dibebankan kepada APBD. Sebagaimana diatur dalam Pasal 31 Ayat (1) dan Ayat (2) Peraturan Menteri Perdagangan Republik Indonesia Nomor 06/M-DAG/PER/2/2017 tentang Badan Penyelesaian Sengketa Konsumen yang menjelaskan bahwa: “(1) dalam melaksanakna tugasnya, BPSK mengelola biaya penyelenggaraan BPSL yang terrdiri dari: a. biaya operasional; $b$. honorarium ketua, wakil ketua, dan anggota BPSK; dan c. honorarium kepala sekretariat dan anggota sekretariat. (2) biaya penyelenggaraan BPSK sebagaimana dimaksud Ayat (1) dibebankan pada Anggaran Pendapatan dan Belanja Daerah (APBD) provinsi sesuai dengan kemampuan daerah". Sedangkan pada penyelesaian sengketa konsumen melalui LAPS, LAPS memungut biaya untuk setiap sengketa yang diselesaikan sesuai dengan nilai objek sengketa yang akan diselesaikan, dan pembayarannya dibebankan kepada konsumen dan lembaga jasa keuangan yang bersangkutan.

Pada dasarnya hukum perlindungan konsumen merupakan payung hukum yang memayungi ketentuan-ketentuan peraturan perundang-undangan terkait dengan perlindungan konsumen, baik itu konsumen lembaga pembiayaan atau konsumen akhir sebagai mana yang 


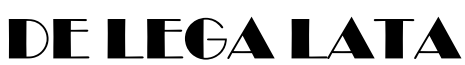

Jurnal Ilmu Hukum

FAKULTAS HUKUM UMSU
Kewenangan Penyelesaian Sengketa...(Titia Tauhiddah, dkk) Volume 5 Nomor 1, Januari - Juni 2020, 94-105 DOI: https://doi.org/10.30596/dll.v5i1.3472

diberikan perlindungannya melalui BPSK. Kedudukan BPSK dan LAPS-BMPPVI dalam hukum perlindungan konsumen sama-sama diatur berdasarkan aturan hukum yang relevan. Namun secara hierarki peraturan perundang-undangan kedudukan BPSK yang diatur berdasarkan UUPK lebih tinggi dari LAPS yang didirikan berdasarkan POJK. Jika dilihat berdasarkan asas hukum lex superior derogan legi inferiori yang artinya hukum yang tinggi mengenyampingkan hukum yang lebih rendah dimana asas ini biasa digunakan untuk hierarki peraturan perundang-undangan, maka dapat kita simpulkan jika kekuatan hukum kedudukan BPSK dalam penyelesaian sengketa konsumen lebih kuat jika dibandingan dengan LAPS dan jika terdapat aturan yang mengatur materi yang sama namun antara aturan UUPK dengan POJK saling bertentangan maka peraturan yang lebih tinggi dapat mengenyampingkan peraturan yang lebih rendah. Sehingga pada dasarnya jika terjadi sengketa pada lembaga pembiayaan dan juga lembaga jasa keuangan lainnya yang mana konsumen berkedudukan sebagai konsumen akhir bukan konsumen antara maka konsumen dapat memilih untuk menyelesaikan sengketa konsumen diluar pengadilan melalui BPSK.

Alasan kenapa konsumen antara tidak dapat memilih menyelesaikan sengketa diluar pengadilan melalui BPSK adalah karena sengketa yang dapat diselesaikan melalui BPSK adalah sengketa yang terjadi pada konsumen akhir lembaga keuangan sebagaimana yang telah dijelaskan sebelumnya. Hanya saja di dalam sektor jasa keuangan juga terdapat konsumen akhir contohnya adalah nasabah lembaga pembiayaan dan asuransi sehingga nasabah jasa keuangan pada sektor pembiayaan dan asuransi dapat memilih menyelesaikan sengketa diluar pengadilan melalui BPSK ataupun melalui LAPS-BMPPVI. Hal tersebut tergantung dari pilihan konsumen dan berdasarkan kesepakatan para pihak akan memilih menyelesaikan sengketa konsumen, namun hak tersebut tidak dapat dipakai secara mutlak begitu saja, akan tetapi harus dengan memperhatikan kedudukan konsumen pada lembaga yang bersangkutan apakah sebagai konsumen akhir atau sebagai konsumen antara.

\section{KESIMPULAN}

Berdasarkan Penjabaran di atas maka dapat disimpulkan bahwa BPSK adalah lembaga penyelesaian sengketa konsumen yang menyelesaikan konsumen melalui jalur non litigasi (luar pengadilan), merupakan lembaga yang didirikan berdasarkan amanat dari UUPK, yang berwenang menyelesaikan sengketa konsumen khusus pada konsumen akhir, yang melindungi konsumen dari setiap kegiatan usaha pelaku usaha yang dapat merugikan konsumen. Dengan kata lain BPSK mendapatkan kewenangan secara langsung dari Undang-Undang. Kewenangan BPSK diatur dalam Keputusan Menteri Perindustrian dan Perdagangan Republik Indonesia Nomor: 350/MPP/Kep/12/2001 tentang Pelaksanaan Tugas dan Wewenang Badan Penyelesaian Sengketa Konsumen dan Peraturan Menteri Perdagangan Republik Indonesia Nomor 06/M-DAG/PER/2/2017 tentang Badan Penyelesaian Sengketa Konsumen. BPSK diawasi oleh menteri dan/atau gurbernur yang dalam hal ini diwakili Kementrian Perdagangan Republik Indonesia dan ditiap daerahnya diwakili dinas yang membidangi urusan perdagangan di pemerintahan daerah provinsi.

Sedangkan LAPS merupakan lembaga alternatif penyelesaian sengketa yang dibentuk oleh Otoritas Jasa Keuangan melalui kerjasama Lembaga Jasa Keuangan yang dikoordinasikan 
DE IFGA LATA

Jurnal Ilmu Hukum

FAKULTAS HUKUM UMSU
Kewenangan Penyelesaian Sengketa...(Titia Tauhiddah, dkk)

Volume 5 Nomor 1, Januari - Juni 2020, 94-105 DOI: https://doi.org/10.30596/dll.v5i1.3472

oleh asosiasi masing-masing sektor jasa keuangan, dibentuk berdasarkan ketentuan POJK Nomor 1/POJK.07/2013 tentang Perlindungan Konsumen Sektor Jasa Keuangan. OJK memberikan wadah kepada konsumen untuk melakukan pengaduan jika terjadi suatu sengketa antara pelaku usaha dengan konsumen, dan OJK juga berupaya untuk menyelesaikan sengketa tersebut melalui wadah yang telah disediakan, dan wadah yang dimaksud adalah LAPS tersebut. LAPS diatur dalam POJK Nomor 1/POJK.07/2014 tentang Lembaga Alternatif Penyelesaian Sengketa Sektor Jasa Keuangan. penyelesaian sengketa jasa keuangan dengan cara non litigasi. untuk untuk penyelesaian sengketa konsumen pada lembaga pembiayaan melalui LAPS dilaksanakan oleh Badan Mediasi Pembiayaan, Pergadaian, dan Ventura Indonesia (BMPPVI). BMPPVI didirikan oleh OJK guna melakukan penyelesaian sengketa konsumen pada sektor pembiayan, pergadaian dan modal ventura.

\section{SARAN}

Bertolak dari kesimpulan diatas, penulis memberikan saran bahwa kehadiran LAPS sebenarnya tidak menganggu kedudukan dan kewenangan dari BPSK, karena kewenangan yang mereka miliki berbeda. BPSK berwenang menyelesaikan sengketa konsumen tingkat akhir dan LAPS menyelesaikan sengketa konsumen antara, hanya saja LAPS juga memiliki kewenangan menyelesaikan perkara konsumen Lembaga pembiayaan walaupun konsumen tersebut adalah konsumen akhir, namun hal ini sebenarnya sangat membatu BPSK dalam menyelesaikan perkara. Hanya saja konsisi BPSK saat ini memang jauh dari kata memadai, dikarenakan dari segi aturan hukum BPSK memiliki aturan hukum yang tidak kuat karena tidak adanya kewenangan BPSK untuk melakukan eksekusi terhadap putusan yang dikeluarkan. Akan lebih baik lagi aturan BPSK direvisi agar kedudukan BPSK lebih kuat dan kewenangan BPSK dalam menyelesaikan sengketa lebih jelas. 
Jurnal Ilmu Hukum

FAKULTAS HUKUM UMSU
Kewenangan Penyelesaian Sengketa...(Titia Tauhiddah, dkk)

Volume 5 Nomor 1, Januari - Juni 2020, 94-105 DOI: https://doi.org/10.30596/dll.v5i1.3472

\section{DAFTAR PUSTAKA}

Gaharpung, Marianus. Perlindungan Konsumen Korban Atas Tindakan Pelaku Usaha, Jurnal Yustika, Vol.III, No. 1, Juli 2000.

Keputusan Menteri Perindustrian dan Perdagangan Republik Indonesia Nomor 350/MPP/Kep/12/2001 Tahun 2001 tentang Pelaksanaan Tugas dan Wewenang Badan Penyelesaian Sengketa Konsumen.

Keputusan Presiden Nomor 61 Tahun 1998 tentang Lembaga Pembiayaan;

Kristiyanti, Celina Tri siwi. (2008) Hukum Perlindungan Konsumen. Jakarta: Sinar Grafika

Nugroho, Susanti Adi. (2011). Proses Penyelesaian Sengketa Konsumen Ditinjau Dari Hukum Acara Serta Kendala Implementasinya. Jakarta: Kencana

Peraturan Otoritas Jasa Keuangan : Pengumuman Nomor Peng-1/D.07/2016 tentang Daftar Lembaga Alternatif Penyelesaian Sengketa di Sektor Keuangan.

Peraturan Otoritas Jasa Keuangan Nomor 1/POJK.07/2013 tentang Perlindungan Konsumen Sektor Jasa Keuangan.

Peraturan Otoritas Jasa Keuangan Nomor 1/POJK.07/2014 tentang Lembaga Alternatif Penyelesaian Sengketa Sektor Jasa Keuangan.

Sidabalok, Janus. (2014). Hukum Perlindungan Konsumen Di Indonesia. Bandung: Citra Aditya Bakti

Undang-Undang Nomor 21 Tahun 2011 tentang Otoritas Jasa Keuangan.

Undang-Undang Republik Indonesia Nomor 8 Tahun 1999 tentang Perlindungan Konsumen. www.bmppvi.com/profil/. 